\title{
Problem Overview about Family Financial Discussion on Pre-Marriage Course Module in Malaysia
}

\author{
Millah Hanifah, Mohd Noor Daud
}

To Link this Article: http://dx.doi.org/10.6007/IJARBSS/v11-i4/9698

DOI:10.6007/IJARBSS/v11-i4/9698

Received: 12 February 2021, Revised: 14 March 2021, Accepted: 02 April 2021

Published Online: 20 April 2021

In-Text Citation: (Hanifah \& Daud, 2021)

To Cite this Article: Hanifah, M., \& Daud, M. N. (2021). Problem Overview about Family Financial Discussion on Pre-Marriage Course Module in Malaysia. International Journal of Academic Research in Business and Social Sciences, 11(4), 534-541.

\section{Copyright: @ 2021 The Author(s)}

Published by Human Resource Management Academic Research Society (www.hrmars.com)

This article is published under the Creative Commons Attribution (CC BY 4.0) license. Anyone may reproduce, distribute, translate and create derivative works of this article (for both commercial and non-commercial purposes), subject to full attribution to the original publication and authors. The full terms of this license may be seen at: http://creativecommons.org/licences/by/4.0/legalcode

\section{Vol. 11, No. 4, 2021, Pg. 534 - 541}

Full Terms \& Conditions of access and use can be found at http://hrmars.com/index.php/pages/detail/publication-ethics 


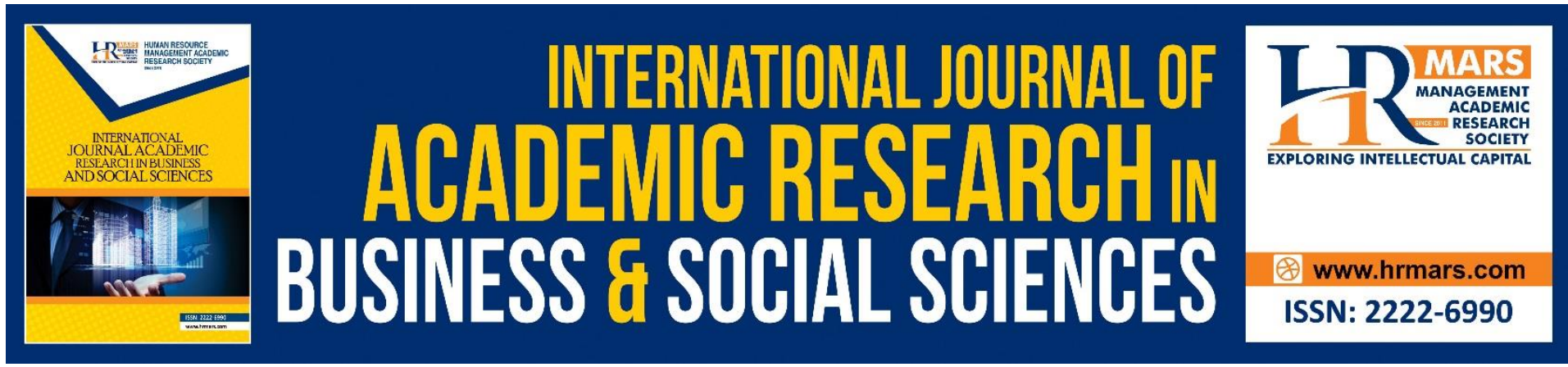

\title{
Problem Overview about Family Financial Discussion on Pre-Marriage Course Module in Malaysia
}

\author{
Millah Hanifah, Mohd Noor Daud \\ Sultan Idris Education University, 35900 Tanjong Malim, Perak, Malaysia \\ Email: milahanifahplogie@gmail.com
}

\begin{abstract}
Pre-marriage courses are introduced to prepare prospective husbands and wives mentally. In Malaysia, family financial management modules are also included in marriage courses. This study was conducted to explain the problems of family financial management's benefits in the pre-marriage course module in Malaysia and to identify the theory of maslahah and family financial management benefits by using a qualitative approach then will be analyzed through descriptive analysis methods. The findings show that the family's financial management in the pre-marriage course has several benefits. It becomes a dharuriyyat need or a fundamental need to maintaining the property. The findings are expected to help parties of pre-marital courses to discuss or improve family financial management on course modules, so it can create of a harmonious and wise family in leading the family economy
\end{abstract}

Keywords: Pre-Marriage Course, Financial, Maslahah

\section{Introduction}

Pre-marriage courses are a social phenomenon that happening now and also an important thing in the law of marriage. And this is a forum that provides short-term learning to improve the knowledge, skills, and mental attitude of a man and woman who will bond with each other in a marital relationship and build a household together.

The pre-marriage course's objectives are to provide basic knowledge covering religious aspects and problem-solving skills in marital conflict, financial management, and potential health problems and reduce the level of divorce among married couples (Syarifah \& Suhaili, 2018).

In Malaysia, pre-marriage courses use the Integrated Module of Islamic Pre-Marriage Courses (MBKPI). This module contains 11 topics, one of them is family financial management.

This study is different from previous studies because they previous study only focus on the discussion of financial management in pre-marriage courses. Meanwhile, this study discusses the family financial management found in the book entitled "Entering the Marriage Gate" published by the Department of Islamic Religious Development Malaysia and reviewed it with maslahah theory. 
The purpose of this study is to find out the level and benefits in the discussion of family financial management in pre-marital courses. This study has several parts, namely: introduction, previous study, methodology, findings and discussion.

\section{Previous Study}

Previous studies show the importance of pre-marital courses for a couple who want to get married. Financial problem is the major problems in marriage and the main causes that lead to divorce.

The First study that show the importance of pre-marital courses from Jamal (2019) was conducted a study on the Pre-Marriage Course Program and reviewed it using Maslahah Theory. It concludes that the family's knowledge is the main basis for creating a happy and loving family. Therefore, the aspect of knowledge in this premarriage course becomes a dharuriat need for husband and wife.

Secondly from Luthfi and Rifa'l (2018) were conducted a study on pre-marital courses as one of the strategies to prevent divorce. This study was conducted on Bimas Islam Ponorogo Regency. He recommended to the Guidance of the Muslim Community of Ponorogo Regency to continue to guide the community, especially couples, in building a family so that each family can create a sakinah mawaddah wa rahmah family following the main purpose of marriage as prescribed in Islam.

Thirdly study by Murdiah et al. (entitled "Islamic Pre-Marriage Course: A Preliminary Review." He suggested that the community, especially couples who will be getting married, should be concerned about the Pre-Marriage Course and always get information and knowledge related to household management so that the Muslim family's demands can be met well. The Islamic pre-marriage course emphasizes strong morals and faith so that the family will always on the right religious path and helps each other.

Another study was conducted by Yassin \& Alma'amun (2018), study entitled Family Financial Management and Muslim Pre-Marriage Courses in Malaysia, concluded that financial management is included in pre-marriage courses because financial problems are one of the causes of marital conflict and divorce. Furthermore, this study proves the financial management positively impacts the individual Muslim Malay respondents aged 18 and over, not to married without pre-marriage courses.

\section{Methodology}

A qualitative approach was used in this study. This study used the study of literature because it reveals the theory relevant to the problems studied, namely the theory of Maslahah. It also uses document study because researcher uses documents in the form of notes or family financial management module in the book entitled Entering the Marriage Gate published by the Department of Islamic Religious Development Malaysia. For data analysis, the data are categorized based on the type of equations, then the data is described so that a complete picture of the problem is obtained (Basri, 2003).

\section{Discussion}

\section{Maslahah}

In term of language context, maslahah is goods that is needed by human beings and beneficial for human life itself without causing harm to someone who takes maslahah as a reference in making new laws. 
The benefits are something that human thought will be beneficial for their lives, both to create good things such as pleasures of life and to reject vices such as avoiding danger and hardship. Furthermore, the benefits in Islamic law that reviewed in terms of strength as an argument in determining the law of maslahah are divided into three levels: maslahah dharuriyyah, hajiyah, and tahsiniyah (Syarrifuddin, 2008).

1) Maslahah Dharuriyyah is a need that must be provided, this need is called primary need. The need for Dharuriyah is to maintaining the essential needs of human life. The essential need is to maintain religion, soul, mind, lineage, and wealth with limitless threats. Failure to meet these requirements will result in the threat of five or seven things (preserving religion, soul, intellect, lineage, and wealth It means human security will be threatened both in this world and in the hereafter.

2) Maslahah Hajiyah is secondary needs, which, if not provided, then does not threaten security, but human beings will be difficult (La Jamaa, 2011). Hajiyah, which is an insignificant need, but includes needs that can prevent people from the hardships of their lives. This group is closely related to rukhshah (Mardani, 2014). The secondary need (al-Hajiyah) for human beings is the starting point to something that can eliminate the narrowness, alleviate the onerous burden in worship, worship and the implementation of uqubah / punishment (Faisal Haq, 2007) .

3) Maslahah Tahsiniyah is needs to support the improvement of one's dignity in society and before God, following obedience. The things that become complementary needs begin with everything that makes the human condition beautiful and makes it following the demands of norms and pure values. The goal of tahsiniyat (tertiary) Islamic law is the laws which aims to perfecting human life by carrying out what is right and appropriate and avoiding embarrassing things (Juahaya, 1995).

According to Amin (2011), acceptable maslahah or mu'tabaroh is an important maslahah, which includes five basic guarantees that can be categorized based on the quality and importance of benefits, such as:

1) Maintaining the Religion

That is by avoiding the slander and salvation in religion and embracing action that leads to the destruction of human passions. Religion is a collection of creeds, worship, laws, and laws established by Allah SWT to regulate the relationship between humans and God and human relations between one another (Wahhab, 1997).

2) Maintaining the Soul

It is a guarantee for the safety to live nobly and respectfully. The soul is a significant human property because the soul represents life. One of the wisdoms of the syaria'ah existence is the regulation that protects the human soul to avoid the tyranny of others. The right to life is a non-negotiable right and must be defended. A person's blood must not be spilled without a good reason (Ya'qub, 1995).

3) Maintaining the Mind

It is the mind's guarantee from damage that maintaining it away from various harmful things in the mind. The mind is the thought or rationale possessed by human. Because human is 
gifted with intellect, he will be able to grow and develop. The human mind can develop because the environment influences it (Khallaf, 1997).

4) Maintaining the Lineage

It guarantees the life and human growth to stay alive, healthy and strong, both in character and spiritual development. Lineage are gharizah or instinct to create a heredity. In order to maintain that legal family, God wants the human being to perform a marriage (Syarifuddin, 2008).

5) Maintaining the Wealth

That is to deviate life from the economy in a halal way, not from a way that is fraudulent and wrong. Wealth is something that human beings desperately need so that human beings are always driven by the desire to have much wealth. The human desire to consume property (edible things) is unsatisfactory. To regulate property, Islam has applied the rules of mu'amalat (human sesame relations), prohibiting stealing, cheating, usury, gambling, and damaging others' property. Islam has set a punishment for people who steal, that is, cut off their hands (Bakry, 1993).

\section{Family Financial Management in Pre-Marriage Course Module.}

In the pre-marriage course, the discussion on finance became one of the important things because many households were destroyed due to economic problems. So that family financial problems need to be managed wisely to stabilize the economy to meet the needs of the family. Family financial discussions on pre-marriage courses include:

1) Purpose or Importance of Financial Management.

This chapter discusses some of the purposes or importance of family financial management. such as:

a) Controlling Family Expenditure.

The head of the family needs to ensure a source of income to finance the family in a halal way and monitor the family expenses because the head of the family can ensure that the family finances are well managed. As Allah SWT. It says in surah al-Furqan verse 37:

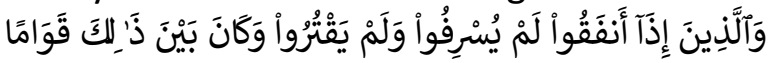

This means: and also those (who are pleased with Allah) who, when spending their wealth, do not exceed the limits and are not stingy; and (on the contrary) their spending is moderately right between the two ways (extravagant and stingy).

b) Bea good consumer

Families need to be a smart consumer by spending according to needs. They need to control themselves from being easily influenced by various cheap offers and promotions by traders. A wise family will spend prudently and according to need only.

c) Save for the future

Efficient financial management is frugal. By using a frugal approach, families will have savings. When the family has savings, family members will plan various things to strengthen family life, such as family assets, performing Hajj, and others. 
2) Family Expenditure Planning

Family needs to create a spending planning that in line with the family's finances and capability. When planning family expenses, couples need to take the following into account:

a) Set the goals

Wise financial management allows husband and wife and the whole family to allocate daily expenses, own a house, vehicle, own an education fund for children, make emergency savings, old age savings, and other needs. Goals like this are essential because they can avoid bearing the burden of debt and can ensure well-being.

b) Identify the capability of the family

Families need to know the amount of income earned to make detailed plans, so that family expenses do not exceed the income. Identifying the capability is also important to avoid debt burden, serious financial problems, and wasteful habits. Many couples who do not identify the family's financial capabilities can lead to marital discord and divorce.

3) Expenditure category

There are three expenditure categories, namely:

a. Dharuriyyat

Dharuriyyat is the expenditure of daily necessities such as food and drink, shelter, clothing, education, medicine, and others.

\section{b. Hajiyyat}

Hajiyyat is a need that complements basic needs, such as having a fan, vehicle, refrigerator, lights, and so on.

\section{c. Tahsiniyyat}

Tahsiniyyat is spending on luxuries, such as owning luxury vehicles, jewelry, luxury furniture, and so on.

\section{Allah SWT. says in surah al-Isra 'verses 26-27: وَلَالَتُبَِّّز تَبِِْْيرًا

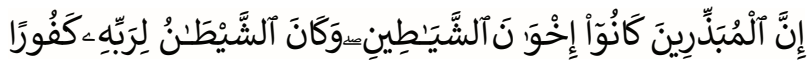

This means: In carrying out expenses, the husband and wife should prioritize expenses that fall into dharuriyyat. If this dharuriyyat has been met, then the excess expenditure can be used for hajiyyat needs. If there is a surplus of hajiyyat, it can be used for tahsiniyyat needs. According to the order of the categories, financial management will lead to the well-being of the household.

\section{4) Record, check and evaluate Expenditure}

The things that husband and wife need to do to control spending are:

\section{a. Plan a purchase}

Plan the items to be purchased and purchase the items that have been listed

b. Buy in cash 
Buying goods in cash is better. Because the price of goods is cheaper, there is no debt burden and can control expenses and avoid wastage. However, if you have to go into debt, make sure to buy only the necessary items and afford to pay in installments every month. In debt

c. Practice the principle of prudence and harmony (Qanaah)

Practicing prudence and qanaah (in line with what is available) is the best way to manage family expenses. Prudent expenses are those that are made based on real needs as well as available capabilities. If expenses are made beyond the means and not guided by needs, it will cause problems.

d. Savings

Every family should have financial savings for the purpose of:

a) wife's maternity and family member's sick

b) Buying assets

c) Children's education

d) Accident

e) Performing worship, especially Hajj

f) Leisure and recreation

5) The Impact of Good Financial Management

Among the effects of good financial management are as follows:

a. Creating a harmony household

b. The family economy is stable and robust

c. Avoid waste and debt burden

d. All planning can be implemented in an orderly and easy manner

e. Households are blessed and pleased by Allah SWT.

\section{Conclusion}

According to this study results, it can be concluded that the pre-marriage course is an advice that aims to remind people or Muslims about religion and the guide of life in the world based on the verses of the Qur'an and Hadith. The content outlined in the topic of family finance in the pre-marriage course includes financial management, whether short-term or long-term property management. To be the necessity of dharuriat for husband and wife. Furthermore, this step should be done because it coincides with the goal / maqasid Syariah to take care of property also coincides with the goal / maqasid Syariah specifically in a marriage that is to maintain harmony of the Muslim household (the concept of Mawaddah wa rahmah) as emphasized in the Qur'an.

\section{References}

Khallaf, A. W. (1997). IImu Ushul Fikih. Kuwait: Darul Qalam.

Syarifuddin, A. (2008).Ushul Fiqh, Jilid 2. Jakarta : Kencana Prenada Media Group.

Bisri, C. H. (2003). Model Penelitian Fiqh, Paradigma Penelitian Fiqh Dan Figh Penelitian. Jakarta: Rawamangun.

Haq, F. (2007). Ushul Fiqh: Kaidah-Kaidah Penetapan Hukum Islam. Surabaya: PT. Citra Media, Ya'qub, H. (1995). Pengantar Hukum Syari'ah (Hukum Islam). Bandung: CV. Diponegoro.

Jamal, I. M. (2019). Program Kursus Pra Nikah Ditinjau Dari Teori Maslahah, Journal Legitimasi, $8(2), 141-158$. 
Jabatan Kemajuan Islam Malaysia. (2016). Memasuki Gerbang Perkahwinan, Kuala Lumpur: Aslita Sdn Bhd.

Praja, J. S. (1995). Filsafat Hukum Islam. Bandung: Pusat Penerbitan Universitas.

Jamaa, L. (2011). Dimensi Ilahi dan Dimensi Insani dalam Maqashid Syariah. Jurnal Asy-Syir'ah, 45(2), 1251-1270.

Amin, M. (2011). Fatwa dalam Sistem Hukum Islam. Jakarta: elSAS.

Mardani. (2014). Ushul Figh, Jakarta: Rajawali Pers.

Luthfi, M., \& Rifa'l, M. (2018). Bimwin Sebagai Strategi Komunikasi Bimas Islam Kabupaten Ponorogo Dalam Mencegah Perceraian, Dalam Jurnal Komunikasi, 12(2), 87-96

Bakry, N. (1993) Fiqh dan Ushul Fiqh. Jakarta: PT.Rajawali Press.

Romli. (2017). Pengantar Ilmu Ushul Figh. Depok: PT. Karisma Putra Utama.

Yassin, S. N. N., \& Alma'amun, S. (2018). Pengurusan Kewangan Keluarga Dan Kursus Pra Perkahwinan Muslim Di Malaysia, International Research Management \& Innovation Conference, Palm Garden Hotel Putrajaya, 1-20.

Murdiah, S., Dan Rahimah, N. O. (2020). Kursus Praperkahwinan Islam: Satu Tinjauan Awal, Trengganu: Universiti Sultan Zainul Abidin. 1-8.

Syakirin, A. (2020) Interview of "Kursus Pra Perkahwinan" on Pejabat Pentadbiran Agama Islam Daerah Muallim, Jalan Rumah Rehat Kampung Kurnia, Perak, Malaysia. 